\title{
Insights on monetary policy and public banking in Brazil (2008-2012)
}

Uma avaliação dos bancos públicos e da política monetária no Brasil no período 2008-2012

Elena Soihet

Rural Federal University of Rio de Janeiro (UFRRJ)

Cesar Murilo Nogueira Cabral

Rural Federal University of Rio de Janeiro (UFRRJ)

\section{Abstract}

This paper aims to analyze the effect of monetary and banking policy during the subprime crises between 2008 and 2009 and afterwards (2010-2012). The main actions and the monetary policy of the Brazilian Central Bank are also discussed. We found that at the peak of the crisis, the main lever for restoration of the Brazilian economy was related to domestic economic policy measures, particularly the ones implemented by the main state-owned banks: Caixa Econômica Federal, Banco do Brasil and Banco Nacional de Desenvolvimento Econômico e Social. The supporting role of other economic policies and the external economic environment are also discussed here. The findings show that in the period immediately following the crisis, (2010-2012), both credit and monetary policies did not succeed in ensuring sustained economic growth.

\section{Keywords}

state owned banks; credit market; monetary policies.

JEL Codes E44; G21; G29.

\section{Resumo}

O presente trabalho tem como proposta mostrar a atuação dos principais bancos públicos brasileiros durante a crise do subprime (2008-2009) e no periodo posterior, de 2010 a 2012. Ademais, será analisada a atuação do Banco Central e os principais instrumentos de política monetária. Será evidenciado que, no auge da crise, a principal alavanca para restauração da economia brasileira esteve relacionada às medidas de política econômica interna, sobretudo via atuação da Caixa Econômica Federal, Banco do Brasil e Banco Nacional de Desenvolvimento Econômico e Social. Nesse sentido, as demais políticas econômicas tiveram um papel coadjuvante assim como o cenário externo. Por outro lado, no período imediatamente posterior, 2010-2012, tanto a política creditícia como a monetária não foram bem sucedidas em assegurar um crescimento sustentado da economia.

\section{Palavras-chave}

bancos públicos; crédito; política monetária.

Códigos JEL E44; G21; G29. 


\section{Introduction}

In the first decade of the $21^{\text {st }}$ century, global economies were shaken by the North American subprime mortgage crisis in 2008. In fact, the crisis had been building out since 2001, with the beginning of real estate speculation in the United States associated with low interest rate policy implemented by the Federal Reserve Bank (Fed) due to low inflation rates at that time.

The continual increase of the Fed discount rate for US bonds, from $1.58 \%$ to $3.5 \%$ per year in September 2004, and then reaching $5.03 \%$ per year in September 2007, ${ }^{1}$ soon became a decisive factor affecting the subprime mortgage holders who were not meeting their commitments. The financial crisis began in 2008 and escalated considerably from mid-September onward. The decision of American authorities to give no financial support to Lehman Brothers in September 2008 further aggravated the crisis, causing strong impacts on global markets (Borça Júnior; Torres Filho, 2008, p.132).

In response to this transmission of the crisis and negative outcomes resulting from a context of panic and capital runs, the Brazilian government adopted countercyclical measures, particularly concentrated in the main federal public banks: Banco do Brasil [Bank of Brazil] (BB), Caixa Econômica Federal [Federal Savings Bank] (CEF) and Banco Nacional de Desenvolvimento Econômico e Social [National Bank for Economic and Social Development] (BNDES). ${ }^{2}$ On the other hand, Banco Central do Brasil [Central Bank of Brasil] played a secondary role and was somehow incoherent in its policy intended to foster liquidity. During the peak of the crisis, Banco Central stimulated liquidity through reserve requirements and Open Market operations. However, other monetary policies were not countercyclical, the rediscount policy was not used, and the reduction in basic interest rates happened far too late and was useless to promote economic recovery.

Despite more than six years passing since the beginning of the international crisis, the debate about the need for public banks still holds and gives rise to controversies, particularly in Brazil. On the one hand, economists more aligned with liberal ideas claim that capital is badly allocated in

1 Discount rate in the North American market at end-of-period, International Finance Statistics, $<$ www.imf.org/external/data.htm>, retrieved on 7 January 2015.

2 Brazil has also two other federal banks acting regionally: Banco do Nordeste do Brasil [Bank of the Northeast of Brazil] (BNB) and Banco da Amazônia [Bank of Amazon] (BASA). 
public banks; on the other hand, economists with a more developmental approach argue that public banks exist to grant credit. This debate also emerged during the 2014 presidential debate in Brazil. ${ }^{3}$

This paper discusses monetary policy and the role of public banks in Brazil. In particular, we focus on: a) public banks' credit expansion during the subprime mortgage crisis from 2008 to the end of 2009 and afterwards, from 2010 to 2012, and b) Banco Central's monetary policy and relevant legislation during these periods. In Section 2, we provide a theoretical framework for different viewpoints on public banking systems. In Section 3 , we present a historical overview of Brazil's main public banks in the face of development policies from 1900 onwards. In Section 4, we analyze both Banco Central's monetary policy and the role of Brazilian public banks during and in the wake of the subprime mortgage crisis (2008-2009 and 2010-2012, respectively). We conclude discussing the findings of the study and its impact on Brazil's current economy.

\section{A theoretical framework for public banking systems}

Originally, the classical theory of banking firms was based on the conception that banks were only responsible for mediating the transference of resources from surplus units to deficit units. As argued in Gurley and Shaw (1955), banks are neutral firms with the purpose of canalizing resources and thus do not affect real variables such as product and investment.

Using a conventional approach, Shaw (1973) and McKinnon (1973) were the first to explain the notion of financial repression. The authors argued that several countries, including some developed ones, have historically restricted competition in the financial sector by using government interventions and regulations in order to provide low-cost credit. According to them, a repressed financial sector discourages savings and investment due to lower rates of return when compared with a competitive market.

Shaw (1973), McKinnon (1973) and Hermann (2003, p.39) use the term "financial repression policy" to explain that its effect is to constrain, and

3 The economic staff of then candidate Aécio Neves minimized the relevance of these institutions' economic policies. See Armínio Fraga's interview to Rodrigo Constantino from The Liberal Institute, available at $<\mathrm{http} / / \mathrm{ww} w$.institutoliberal.org.br/?s=arminio+fraga $>$, Accessed on July 2013. 
not stimulate, financial development. Aside from fixing target private interest rates, such policy includes, among others, the action of public banks as long-term credit suppliers to strategic sectors for development.

According to Freitas (2010, p.334), research on public banks' efficiency intensified during the World Bank's compilation of an extensive database of financial systems. It focused on measuring public banks' competitiveness in comparison to private banks and concluded that the former are less competitive than the latter. The mainstream's interest in such research was largely related to the process of privatization which took place particularly in Latin America and Southeast Asia.

La Porta et al. (2000) claim there are two main lines of conventional thought. The first is associated with Alexander Gerschenkron (1962) and focuses on the need for public financial institutions to foster development and economic growth. This is the case of Russia in the 19th century which, different from Germany, did not have private banks to foster economic growth and public banks played the part of industrial banks. In line with this viewpoint, some authors, who were in favor of public banks, pointed out the successful cases of India and other Asia countries. Myrdal (1968), for example, stated public banks are important as they provide essential economic sectors with credit, which positively impacts economic growth. These ideas were largely adopted in the 60s and 70s, mainly in Africa, Asia and Latin America, where the government nationalized several commercial banks.

In line with conventional thought, some authors defend public banks as they can resolve problems of market failures. According to Thorton, J. (2011, p.5), development banks are a form of governmental intervention in the financial system and provide finance and credit to sectors which are not well served by the private sector during market failures. They include the social benefits of non-commercial social projects; long-term projects; risk management projects, such as the ones demanding new technologies; projects implemented in poor or distant regions and small or new projects without collateral guarantees. The author sets forth six principles under which development banks become effective instruments: favorable environment, mandate regulation, supervision, governance, financial management and performance evaluation. The author also argues that whilst development banks are still an uncertain initiative for governments, by way of correct circumstances and proper supervision, they can become a useful tool for governments to achieve their goals. That is, to be a channel of society development. 
Contrary to the developmental approach, the 'political' viewpoint, supported by some authors aligned with the market perspective, considers that, through funding, public banks politicize the allocation of resources to gain votes, do not pursue budgetary constraints and thus have low efficiency. The idea of corruption, bureaucratic state incompetence and privatization support are emphasized, along with the idea that public institutions only exist for political, not economic, reasons.

Caprio et al. (2004) provide several arguments to justify the inefficacy of public banks. When analyzing these banks through conventional financial indexes, such as return on equity, default levels and expense levels, they perform worse than private banks. Some public banks are used for granting subsidized loans and credit to particular industries or enterprises determined by the government. They also argue that public banks overload their governments with large liabilities due to explicit guarantees or the implicit assumption that some of them are 'too big to fail'. For the authors, public banks have worse financial indexes when compared to private banks, show less profitability due to subsidized or directed credits and, by playing the part of lenders, are ultimately encumbered with liabilities. Economically speaking, privatization is the best policy for governments with a history of low-performing public banks. Not only can this solution save public money by eliminating subsidies, but it can also improve the performance of their economies by insuring credit is channeled through the market and not through government officers.

When investigating the instruments available to control the banking crisis, Guinle (1999) examined promotion, merger, and bailout of economically unfeasible banks, as well as reduced state participation in the banking system.

[Public banks] have always been a source of poor credit administration, administrative inefficiency, low profitability and more recently in the emergent world, synonymous with default due to direct political interferences. The privatization of state banks is an instrument of reconfiguration of the system bringing stability and uniform treatment to industry (Guinle, 1999, p.41).

Besides additional theoretical arguments to support public banks, Oreiro, Paula and Basílio (2010, p.34-36) show that, available empirical evidence is suggestive of their negative effects on financial development and economic growth in low-income countries, although this claim requires further study. They also state that public banks have a less procyclical credit character than private banks, causing them to reduce cyclical fluctuations. 
According to empirical evaluations based on Brazilian data, Coelho (2007, p.2) argues that the competitive effect of public banks is smaller than private banks', insofar as while private banks stimulate competition, public banks are at best neutral as far as competition is concerned.

In short, conventional literature regards public banks as sources of poor credit administration under current market perspectives. On the other hand, according to the developmental approach, public banks are essential to cover market failures in granting finance and credit to sectors poorly assisted by the private sector.

Different from the traditional approach, where savings continues to be the major constraint to investment expansion, post-Keynesian economics claims that interest rates are a monetary phenomenon that affects businessmen's decision-making regarding investments and are not, as argued by classicists, a result of interaction between capital supply and demand. Under this viewpoint, it is worth discussing the Finance-Investment-Savings-Funding (FISF) circuit and Minsky's (1986) 'Stabilizing an Unstable Economy'.

According to the theory of borrowed funds, ${ }^{4}$ the banking system, particularly commercial banks, is mechanical, static and passive, that is, it is neutral as long as it has no significant impact on economic behavior. In turn, in the finance-investment-savings-funding circuit, the financial system plays an active role in economic growth and it is not simply responsible for resources allocation in deficit and surplus spending units.

Studart (1993, p.106) states there are three issues concerning the circuit. First, in economies with the most developed banking systems, investment finance allows the subsequent creation of income through the multiplier effect. Second, the calculation of the interest rate results from the wealth holders' preference for liquidity in the financial form and the banks' decisions. And third, funding can be a relevant factor to reduce financial weakness which tends to increase in economies whose financial investments are based on bank credit. This analysis also emphasizes the relevance of the financial system's structuring and its articulation with the productivity sector. According to Studart (1993, p.113), there are two basic distinct finance-funding mechanisms consistent with the financial system's structuto an economy with developed monetary system. The introduction of money in the neoclassical framework of the theory of borrowed. 
re that affect financial stability: one, the system based on capital markets, similar to the American model, and second, the system based on the credit market, associated with the German model and predominant in universal banks. In the American model, direct (not intermediated) relations gain great importance in relation to the weight of financial intermediation and are thus more sensitive to the oscillations in asset markets. However, in the German model, stability of interest rates is essential if enterprises are predominantly funded by bank credit.

According to Minsky's (1986) 'Financial Instability Hypothesis' (HIF), the capitalist economy is characterized by a sophisticated and complex financial system with a financial structure comprised of three types of units: hedge units, speculative units and Ponzi units.

Hedge units rely on cash flow from capital asset operations (or financial borrowed contracts) to be more than enough for the payoff / discharge of current and future contractual agreements. Therefore, as these units cannot have a great amount of on call deposit, they are considered the most conservative ones. On the other hand, speculative units rely on cash flow from asset operations (or possession of financial contract) to be smaller than typically short-term payment commitments in some periods. Speculative financial transactions involve rolling over maturing debt and are considered less conservative than the hedge units. Finally, Ponzi units have higher financial costs than income and thus the nominal debt amount increases, an extremely speculative stance.

In short, the solidity or fragility of a financial system depends on the amount and strength of safety margins and the potential increase of initial disturbances. While hedge units settle outstanding debts integrally, Ponzi units are highly leveraged and pose high risks as they indicate their future commitment.

It is worth noting that the way out of a financial crisis, as proposed by Minsky's (1986) post-Keynesian view, may be similar to the conventional approach at first sight as it is associated with market failures. Both support direct government intervention through their public agencies in order to foster growth and development through credit granting. However, in the conventional viewpoint, this intervention is necessary in peripheral markets since they do not have a potential developed market yet.

This approach to market failures is derived from new Keynesian economics and focuses on wage and price rigidity to explain macroeconomic im- 
balances. Although Stiglitz and Weiss also follow this school of thought, they place emphasis on monetary aspects, such as credit and capital markets, in line with our discussion in this paper.

According to Mishkin (2004), market failures occur due to asymmetrical information which causes adverse selections and moral hazards. While adverse selection increases the chances of granting a loan to a bad debtor, moral hazard reduces the probability of loan payments. These are regarded as negative externalities and when both of them fail, bank sectors become more vulnerable. Consequently, this vulnerability results in increases in the interest rate, a stock market drop, an increased level of economic risk and a complete economic collapse causing a bank panic. Due to costs and asymmetrical information risks, not only is the action of the state justifiable to regulate and supervise, but also to act through financial and credit policies.

For Minsky (1986), capitalist economies are inherently unstable. In times of optimism, banks and firms share better expectations and thus economic activity expands. Nevertheless, the agents' debts increase, undermining the economy. Moreover, agents tend to reduce their safety margins and, then, economies acquire a market structure with higher speculative level. On the other hand, in times of pessimism, agents become more careful and increase their safety margins, banks reduce credit and economic activity retracts. In lack of a lender of last resort, panic may spread and cause breakdown of pay systems and bank runs.

To conclude, financial crises and the need for public banks are explained with completely different reasons in both theories. In case of market failure, the economy would be allowed to engage in the free market if there were no friction in labor and bond markets. Minsky (1986) argues that it is crucial that states act continuously to assure more stable cycles.

\section{A historical overview of public banks in Brazil - $B B, C E F$ and BNDES}

The three main public financial institutions in Brazil - Banco do Brasil (BB), Caixa Econômica Federal (CEF) and long-term finance Banco Nacional de De- 
senvolvimento Econômico e Social (BNDES) $)^{5}$ - act as credit agents under federal economic policy. Founded in 1808, Banco do Brasil, aimed at acting both as a commercial bank and monetary authority until the establishment of Banco Central in 1964. On the other hand, Caixa Econômica Federal, founded in 1961, aimed at and encouraged long term savings and lending operations under pledge. BNDES, in turn, was established in 1952 to provide long-term finance at a time when Brazil was making progress with industrialization and development policies. Over time, Banco do Brasil became responsible for federal public credit, Caixa Econômica Federal was in charge of the housing sector and BNDES turned to the industry sector.

In the 1960s, there were substantial changes in the configuration of the Sistema Financeiro Nacional [National Financial System] (SFN). These changes were regarded as the turning point of Brazil's financial system. First, the Lei de Reforma Bancária [Banking Reform Law] (n. 4.595/64), inspired by the North American model, which created institutions aimed at their specialization, established the Conselho Monetário Nacional [National Monetary Council] (CMN) and Banco Central do Brasil (BCB). Other important laws enacted in this period included the indexation instrument known as monetary correction, the Sistema Financeiro da Habitação [Housing Finance System] (SFH) o Banco Nacional de Habitação [National Housing Bank] $(\mathrm{BNH})$ and the reform of the financial market. This format of the SFN prevailed until the mid-1980s. However, a restructure directly affecting public banks took place in 1968 due to a context of chronic inflation and state fiscal crisis. Banco do Brasil lost the current account which placed it as co-responsible for currency issuance through the adjustment of monetary authorities and Tesouro Nacional [National Treasury] accounts. At first, this loss weakened the institution since it no longer relied on previously available resources. CEF incorporated $\mathrm{BNH}$ and became the main agent of the Sistema Brasileiro de Poupança e Empréstimo [Brazilian System of Savings and Loans] (SBPE), manager of the Fundo de Garantia do Tempo de Serviço [Length-of-Service Guarantee Fund] (FGTS) and other SFH funds. In turn, CEF was obliged to bear the costs of the $\mathrm{BNH}$ debt, greatly affecting its operational revenue (Puga, 1999).

5 Banco Nacional de Desenvolvimento Econômico (BNDE) became Banco Nacional de Desenvolvimento Econômico e Social (BNDES) in 1982, when new funding resources were created, such as the Fundo de Investimento Social [Social Investment Fund] (Finsocial, formed by contributions of enterprises' profit and turned to finance social interest activities, thus adding the ' $\mathrm{S}$ ' to the bank's acronym (Hermann, 2010). 
For Hermann (2010), BNDES was the least affected by the default associated with its credit portfolio as it then concentrated on large private enterprises, mostly investment projects prioritized by the II Plano Nacional do Desenvolvimento [National Development Plan] (PND) in the early 1980s. However, Banco do Brasil and Caixa Econômica Federal were affected by the economic crisis due to their high-levels of capital commitment to specific sectors (such as the rural and the housing sectors) and operations (credit to working capital) which were also affected by the recession.

In September 1988, Resolution 1.524 established that the so-called multiple banks should perform at least two and at most four of the previous functions of financial institutions: commercial banks, investments banks, development banks, finance, savings and lending institutions. The result was a process of concentration in the banking sector justified by Banco Central as a consequence of the adjustment to post-Real Plan macroeconomic conditions and in alignment with global merger trends from several productive sectors of modern economies (Camargo, 2009).

After the implementation of the Real Plan in June 1994, there were new reforms in the SFN to promote economic stabilization and reduction of the state's role in the economy. In the state's reform, BNDES played a key role in the privatization program though, since during President José Sarney's government (1985-1990), previous adjustments and definitions of privatization models had already taken place. However, it is worth pointing out that, at that moment, privatization was not a public policy priority as it was in the subsequent governments of Fernando Collor de Mello (19901992) and Fernando Henrique Cardoso (1994-1997; 1998-2002). At the end of Sarney's government, 17 processes of destatization took place with estimated revenue of US $\$ 549$ million and transfer of private sector debt of around US\$620 million (Velasco Jr. L., 2010, p.312).

With the creation of the Programa Nacional de Desestatização [National Destatization Program] (PND) 6 during President Collor's government, privatization became an integral part of the government's economic reforms and the scope and dimension of privatization reform increased substantially. Based on its previous experience, BNDES was chosen to run the program.

6 The Programa Nacional de Desestatização [National Destatization Program] (PND), initially established through Medida Provisória [Provisory Measure] (MP 155), was converted into Law 8.031/90 and subsequently amended until the enactment of Law 9.491/97. 
From 1995 onwards, during Fernando Henrique Cardoso's government, a new phase of the PND began and public services were transferred to the private sector, including the electric power sector and transport and telecommunication concessions. Although out of the scope of the PND, BNDES had an active role in a support program of destatization of state enterprises, particularly the electric power sector, involving the sale of control and minority participations. The main enterprises privatized in the 1990s that were run by BNDES included the mining company Companhia Vale do Rio Doce (CVRD) and the Telebrás system (Velasco Jr., 2010, p.342). The general outcome of privatizations between 1990 and 2002 generated US $\$ 105.8$ billion in revenue (Table 1). In sectoral terms, the PND's major participants were the electrical power sector $(31 \%)$ and the telecommunications sector $(31 \%)$, as depicted in Figure 1.

Table 1 Privatization results- $1990-2002$ ( $\mathrm{R}$ million)

\begin{tabular}{lr|r|r|r}
\hline Period & Sale's Revenue & Transferred Debts & Total Results & Part. (\%) \\
\hline 1990-1994 & 8,608 & 3,266 & 11,874 & 11.2 \\
\hline 1995-2002 & 78,614 & 14,810 & 93,424 & 88.8 \\
\hline Total & 87,222 & 18,076 & 105,208 & 100 \\
\hline
\end{tabular}

Source: Provided by the authors based on BNDES/National Program of Destatization.

Figure 1 Privatization by sectors $-1990-2002$ (In \%)

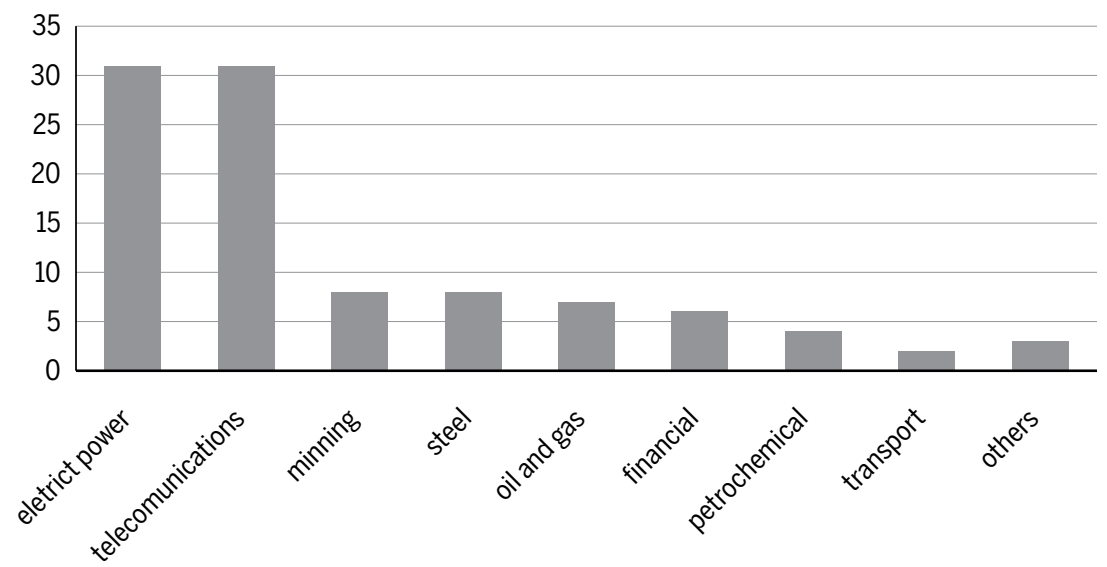

Source: Provided by the authors based on BNDES/National Program of Destatization. 
In addition to privatization, there were also other reform priorities in Fernando Henrique Cardoso's government which affected directly the SFN. Paula, Oreiro and Basílio (2013) claim that the banking system in Brazil has gone through a process of restructuring that has caused deep changes in this sector since the implementation of the Plano Real, such as: the currency Real itself because, with the end of inflation, inflationary revenues until then appropriated by the financial sector were eliminated, modernization and adaption of Brazilian banks to comply with international rules set forth by the Basel Convention I (1998) and adjustment programs, such as Programa de Estímulo à Reestruturação do Sistema Financeiro [ Stimulus Program for the Restructuring of Financial System] (PROER) and Programa de Incentivo à Redução do Setor Público Estadual na Atividade Bancária [Program of Incentives to the Reduction of the State Public Sector in Banking Activities] (PROES). In 2004, the Basel Convention II provided a framework not only for an increase in the banks' minimum capital requirements, according to the Base Convention I, but also for more supervision, transparency and market discipline. While PROER was focused on financial restructuring and caused an increase in mergers, incorporations and the transference of shares among banks, PROES aimed at putting an end to the so-called 'crony loans' used for political purposes without sufficient guarantees. Therefore, Banco Central was often encouraged to aid state institutions, a phenomenon called 'moral hazard'. After the recovery, there was a reduction in the number of financial institutions and public banks, as well as an increase in foreign capital inflows in Brazil. In December 1996, there were 250 commercial banks in Brazil, out of which 32 were public banks, 198 private banks and 41 foreign banks. In 2000, the number of banks was reduced to 192 due to the decrease of the number of public banks (from 32 to 17 banks) and private banks (198 to 175 banks). In contrast, the number of foreign banks increased from 41 to 69 (Table 2).

During the 1990s, there was a reduction in the role of public banks. However, in the 2000s, they regained their relevance, mainly after 2003, when President Lula's government made them their main public policy agents. Besides the traditional activities mentioned before, Banco do Brasil and Caixa Econômica Federal also turned to investments in sectors where private banks were more active. Camargo (2009) shows that, as from 2005, BB strategically expanded its operations 
for non-account holders, a segment where private banks showed considerable growth, such as auto and housing loans and sought partnerships with large retail chains. In turn, CEF started to expand its operations to legal entities.

Table 2 Number of banks (public, private and foreign) ${ }^{7}$

\begin{tabular}{lrrrr}
\hline Banks & $\mathbf{1 9 9 6}$ & $\mathbf{1 9 9 8}$ & $\mathbf{2 0 0 0}$ \\
\hline I. Public & 32 & 22 & 17 \\
\hline II. Private & 198 & 182 & 175 \\
\hline National & 131 & 105 & 93 \\
\hline Foreign Part. & 26 & 18 & 13 \\
\hline III. Foreign & 41 & 59 & 69 \\
\hline Total (I+II+III) & 230 & 204 & 192 \\
\hline
\end{tabular}

Source: Provided by the authors based on BCB/time series.

\section{Brazil's monetary policy and public banking (2008- 2012)}

\subsection{During the subprime mortgage crisis (2008-2009)}

In early 2008, the Brazilian economy went through a period of accelerated growth and greater appreciation of its assets due to the investment grade status it was granted in April 2008, resulting in a stock exchange boom and an increase in credit supply. According to the Annual Report of Banco Central (2009), "all this euphoria caused growing inflationary pressures with inflation exceeding its $4.5 \%$ target band stipulated by the Monetary Policy Committee in June 2008."

Adopting a conservative stance, Banco Central did not reduce the overnight rate - Sistema Especial de Liquidação e de Custódia [Special Clearance and Escrow System] (SELIC) - even with the deterioration of the international economic scenario from August 2008. Between 24 July and 10 September, 2008, the SELIC rate was $13.0 \%$ per year and, at the peak of the crisis (from 11 September, 2008 to 21 January, 2009), COPOM raised the target to $13.75 \%$ (Figure 2).

7 Public banks include federal and state banks. The foreign share on private banks represented 10 to $15 \%$. 
Figure 2 Target of SELIC rate (Jul/2008 to Dec/2008)

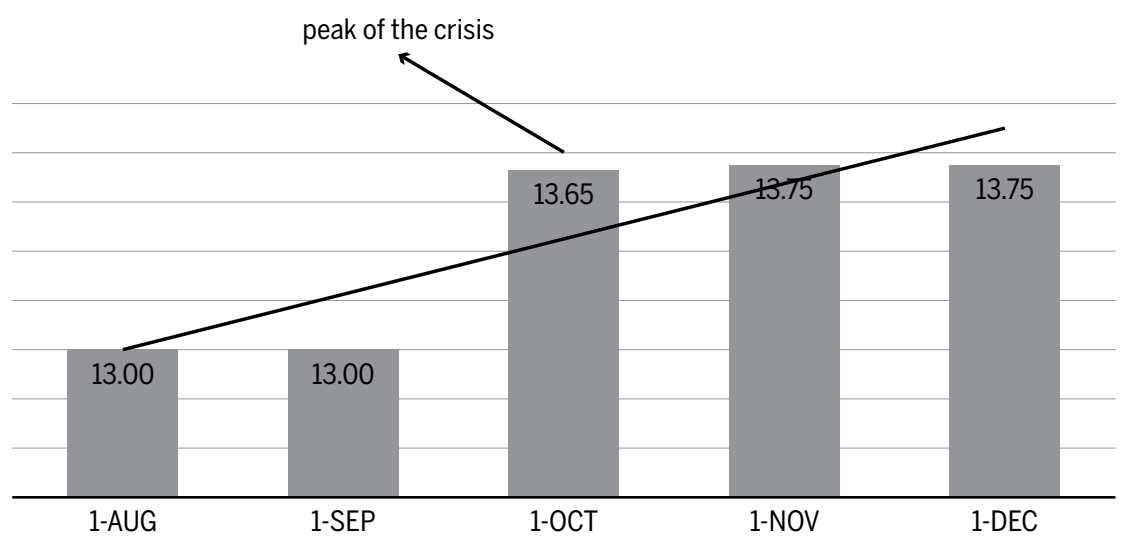

Source: Provided by the authors based on BCB/time series.

In 2009, Banco Central changed its monetary policy as contraction signs could be noted in the pace of economic activity and inflation expectations. COPOM reduced the target inflation rate to $8.75 \%$ in July and it remained unchanged until the early 2010s. Nevertheless, the reduced interest rate, considered a decisive factor in improving future expectations toward the reactivation of aggregate demand, took place too late and, due to a time lag, hindered short-term economic recovery.

During the peak of the 2008 crisis, Banco Central also promoted important changes in reserve requirements to provide the economy with necessary liquidity conditions, as shown in Table 3.

According to Banco Central, these changes enabled the effective release of $\mathrm{R} \$ 100$ billion out of the total balance of this account from September 2008 to January 2009. Almeida (2010, p.57) points out that this release and new banking policies increased relevant liquidity, preventing bank runs and removing any doubts about Brazilian banks' liquidity positions (see Figure 3).

However, there was no unanimous consent about the effectiveness of reducing reserve requirements. As to Freitas (2009, p. 139), the strategy of reducing reserve requirement ratios adopted by Banco Central was useless. Due to private banks' preference for liquidity, for the possibility of cash, and for profitable and low risk application in government bonds, they simply did not expand credit supply. On the other hand, rediscounting was not used as a reserve requirement, since there was some concern that it 
would send the market signals of financial hardship causing liquidity or even a solvency crisis.

It is worth pointing out that, despite the improvement of the rediscounting legal and operational framework, this liquidity window was not used during the crisis. This is largely due to stigma issues, that is, the fact that financial institutions resisted assessing Banco Central's rediscounting line as they were concerned that it would signal hardship and, consequently, would cause more serious liquidity and, eventually, solvency problems (Mesquita; Torós, 2010, p.19).

With regard to the open market, the monetary authority allowed the redemption of $\mathrm{R} \$ 21.2$ million of public bonds in the primary market to increase liquidity during the last quarter of 2008. In 2009, such policy remained the same, though presenting moderate falls (Figure 4).

Table 3 Main changes in reserve requirements (October to December 2008)

\begin{tabular}{|c|c|c|}
\hline Main requirements & Character & Main changes \\
\hline \multirow[b]{2}{*}{$\begin{array}{l}\text { Circular n. 3.408/ } \\
8.10 .2008\end{array}$} & \multirow[b]{2}{*}{ Expansionist } & $\begin{array}{l}\text { 1. Reduction of the additional tax levied on reserve require- } \\
\text { ments for liquid and non-liquid resources from } 8 \% \text { to } 5 \% \text {. }\end{array}$ \\
\hline & & $\begin{array}{l}\text { 2. Increase of the deduction limit for reserve requirements } \\
\text { from } R \$ 300 \text { million (Circular } n .3 .26219 / 11 / 2004 \text { ) to } \\
R \$ 700 \text { million. }\end{array}$ \\
\hline $\begin{array}{l}\text { Circular n. 3.409/ } \\
10.10 .2008\end{array}$ & Expansionist & $\begin{array}{l}\text { Exemption of enforcement of reserve requirements and } \\
\text { compulsory payments of the financial institutes which } \\
\text { formalized rediscounting requests up to the amount of the } \\
\text { operation for the time needed for its analyses. }\end{array}$ \\
\hline $\begin{array}{l}\text { Circular n. 3.410/ } \\
13.10 .2008\end{array}$ & Expansionist & $\begin{array}{l}\text { Increase of the deduction limit for reserve requirements } \\
\text { from } R \$ 700 \text { million to } R \$ 2 \text { billion. }\end{array}$ \\
\hline $\begin{array}{l}\text { Circular n. 3.413/ } \\
14.10 .2008\end{array}$ & Expansionist & $\begin{array}{l}\text { Reduction of the tax levied on reserve requirements on } \\
\text { liquid resources from } 45 \% \text { to } 42 \% \text {. }\end{array}$ \\
\hline $\begin{array}{l}\text { Circularn. 3.417/ } \\
30.10 .2008\end{array}$ & Expansionist & $\begin{array}{l}\text { Reduction of acquisitions and inter-financial deposits to } \\
\text { the limit of } 75 \% \text {. }\end{array}$ \\
\hline $\begin{array}{l}\text { Circular n. 3.426/ } \\
19.12 .2008\end{array}$ & Expansionist & $\begin{array}{l}\text { Reduction of the tax levied on additional enforceability for } \\
\text { non-liquid resources from } 5 \% \text { to } 4 \% \text {. }\end{array}$ \\
\hline \multirow{3}{*}{$\begin{array}{l}\text { Circular n. 3.427/ } \\
19.12 .2008\end{array}$} & \multirow{3}{*}{ Expansionist } & $\begin{array}{l}\text { 1. Reduction of cash installment of reserve requirements of } \\
\text { term deposits from } 70 \% \text { to } 60 \% \text {. }\end{array}$ \\
\hline & & $\begin{array}{l}\text { 2. Inclusion of inter-financial deposits from commercial } \\
\text { lease societies based on the calculation of values subject } \\
\text { to term resource collection. }\end{array}$ \\
\hline & & $\begin{array}{l}\text { 3. Time extension for asset purchase and inter-financial } \\
\text { deposits among financial institutions from December 31st } \\
2008 \text { to March } 31^{\text {st }} 2009 \text {. }\end{array}$ \\
\hline
\end{tabular}

Source: Adapted from Central Bank of Brazil Legislation and Norms. 
Figure 3 Compulsory deposits ( $\mathrm{R} \$$ billions $)^{8}$

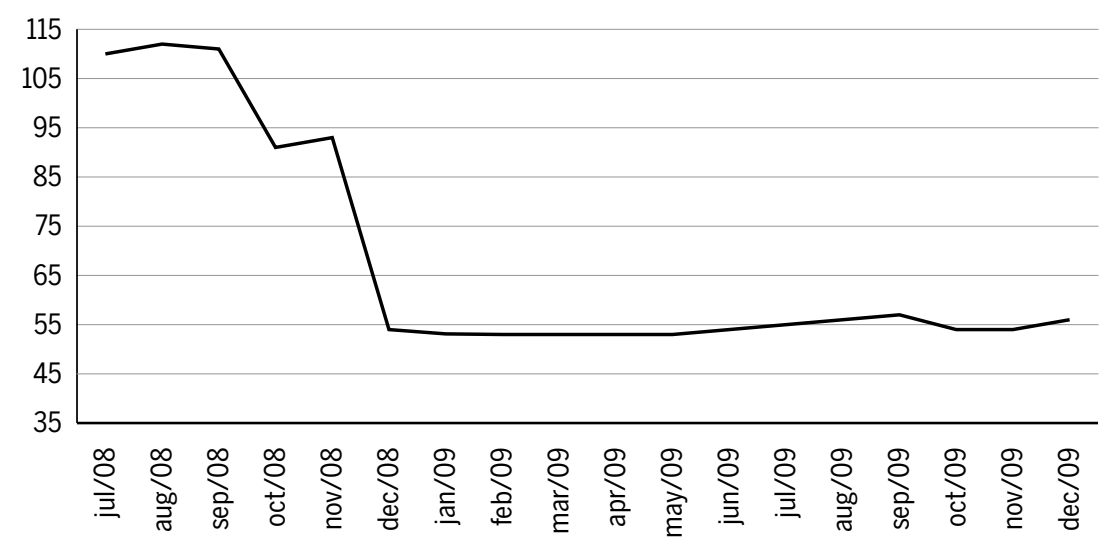

Source: Provided by the authors based on BCB/time series.

Figure 4 Redemption of public securities ( $R \$$ million)

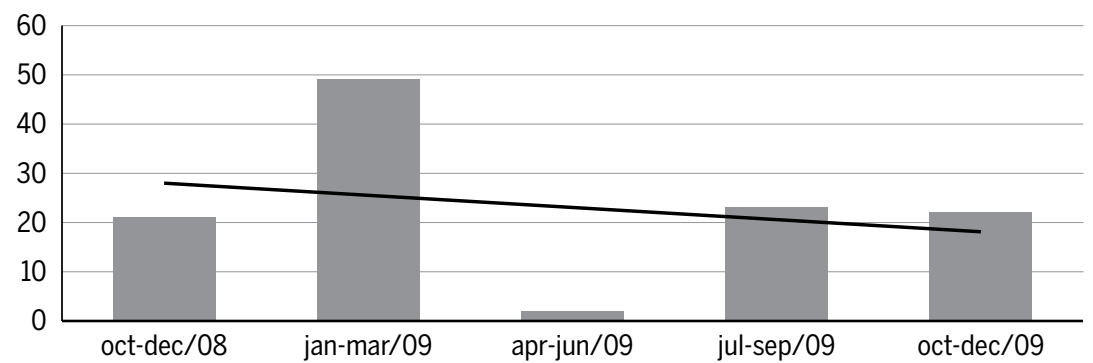

Source: Provided by the authors based on BCB/time series.

That being said, it is safe to say that the monetary policy adopted by Banco Central was focused on only two instruments: reserve requirements and open market. By adopting a careful, though inappropriate, stance, the SELIC rate was not reduced as expected, but rather increased $0.75 \%$ in the critical period of the 2008 crisis.

Before the international crisis, between 2003 and 2007, the Brazilian banking system went through intensive periods of credit granting. For example, the Sistema Financeiro Nacional [National Financial System] (SFN) expanded its credit granting from R $\$ 384.4$ billion (26\% 8 Compulsory deposits ( $\mathrm{R} \$$ billion) are deflated by Indice Nacional de Preços ao Consumidor Amplo [Broad National Consumer Price Index] (IPCA) 
of Gross Domestic Product - GDP) to R $\$ 936$ billion (35.2\% of GDP) mainly through private banks, which increased credit supply from $\mathrm{R} \$$ 371.5 billion (9.7\% of GDP) to R $\$ 917.1$ billion (15.4\% of GDP). On the other hand, public and foreign banks credit granting had a more modest variation in relation to GDP in the same period, as displayed in Figure 5.

Figure 5 Credit of financial system/GDP (Dec 2002 - Dec 2007)

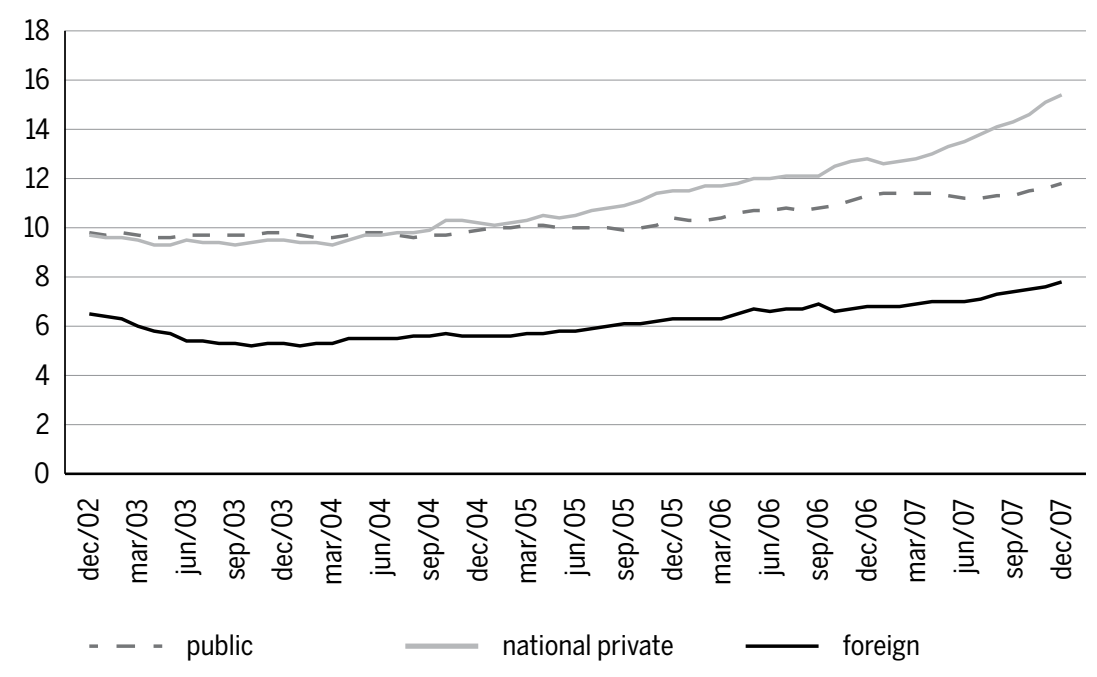

Source: Provided by the authors based on $\mathrm{BCB} /$ time series.

Credit expansion was also a result of the government's policy to boost consumer spending on classes $\mathrm{C}, \mathrm{D}$ and $\mathrm{E}$, and included the following measures: growth of public expenditure, expansion of social protection programs, minimum wage adjustments above inflation and reduction of the SELIC rate to $11.25 \%$, the lowest level since the beginning of Lula's government in 2003, though still very high for international standards (Camargo, 2009).

During the subprime mortgage crisis, private agents were on the defensive regarding credit granting and demanded guarantees due to the confidence crisis instilled in the banking system. The retraction in domestic credit granting was the result of the agents' liquidity preference due to risk aversion and deterioration of expectations in international markets. This situation is discussed by Keynes (2009) as essential properties of interests 
and money: in times of high uncertainty, investors may prefer to hold their wealth in the form of money rather than investing it in capital assets.

It is characteristic /... of money that its yield is nil, and its carrying cost negligible, but its liquidity-premium substantial. Different commodities may, indeed, have differing degrees of liquidity-premium amongst themselves, and money may incur some degree of carrying costs, e.g. for safe custody. But it is an essential difference between money and all (or most) other assets that in the case of money its liquidity-premium much exceeds its carrying cost, whereas in the case of other assets their carrying much exceeds their liquidity-premium (Keynes, 2009, p.189).

From September 2008 to the end of 2009, public banks underwent the hard task of compensating for the stagnation of private credit granting by increasing participation in the SFN by $6 \% .^{9}$ By the end of 2009 , private institutions reduced their participation in the SFN to $51 \%$ (a $9.5 \%$ decrease in relation to September 2008), while public institutions represented $46.5 \%$ of the SFN (an increase of $8.5 \%$ in the same period), as depicted in Table 4.

Table 4 Financial system's loans $(\%)^{10}$

\begin{tabular}{lrrrrr}
\hline Financial Institutions & Dec/02 & Dec/06 & Sep/08 & Dec/09 \\
\hline Public & 38 & 38.2 & 37 & 46.5 \\
\hline Private & 59.7 & 59.2 & 60.3 & 50.8 \\
\hline Others & 2.3 & 2.6 & 2.7 & 2.7 \\
\hline Total & 100 & 100 & 100 & 100 \\
\hline
\end{tabular}

Source: Provided by the authors based on BCB/Credit and Banks Economic Report, 2009.

Between September 2008 and December 2009, credit operations in BNDES, Caixa Econômica Federal and Banco do Brasil increased R $\$ 204$ billion, while in private institutions the increase was only $\mathrm{R} \$ 22$ billion. This shows that public institutions granted almost ten times more credit than private institutions (Table 5). The figures demonstrate how vigorous, dynamic and successful the public banks' credit policy became at the peak of the international crisis. In order to reverse the state of deterioration of economic expectations, not only did the government encourage economic recovery, but also kept inflation within the target band established by Banco Central.

9 Besides increasing credit supply, Banco Central reduced reserve requirements and adopted other macroprudential policies to increase market liquidity.

10 The 50 major financial institutions correspond to nearly $98 \%$ of total financial system. 
Table 5 Total of credit ( $\mathrm{R} \$$ billions)

\begin{tabular}{lrrrr}
\hline Financial Institutions & Sep/08 & Dec/09 & $\boldsymbol{\Delta}$ \\
\hline BB & 175.6 & 261.8 & 86.2 \\
\hline CEF & 63.3 & 115.5 & 52.2 \\
\hline BNDES & 88.4 & 153.8 & 65.4 \\
\hline Private & 596.8 & 618.9 & 22.1 \\
\hline Total & 924.1 & 1150 & 225.9 \\
\hline
\end{tabular}

Source: Provided by the authors based on BCB/Credit and Banks Economic Report, 2009.

Therefore, in line with Oreiro, Paula and Basilio (2010), it seems evident that there was indeed a political policy making to encourage the major Brazilian public banks to expand credit operations as part of countercyclical measures in the domestic market.

\subsection{In the wake of the subprime mortgage crisis (2010-2012)}

In 2010, the Sistema Especial de Liquidação e de Custódia (Special System for Settlement and Custody) SELIC ${ }^{11}$ rate increased $2 \%$ per year ranging from $8.75 \%$ in January to $10.75 \%$ in December. The Monetary Policy Committee`s (COPOM's) justification for the increase was to assure the inflation's convergence to the center of the target band. While the SELIC rate increased throughout the year, GDP increased $7.5 \%$, the highest level since 1986. That year, with the tax and credit incentives all sectors achieved substantial growth; for example, animal farming grew $6.5 \%$, industry (mostly durable goods) grew $10.1 \%$ and services grew $5.4 \%$.

During the course of 2011, the SELIC rate presented two distinct paths: until August, it increased $2.25 \%$ and from September on, there was a more accelerated decrease reaching $11 \%$ per year. In the first semester, COPOM was more concerned with the inflation target and adopted a more conservative policy: not only did it increase the SELIC rate, but also implemented macro-prudential tools, such as increases in reser-

11 SELIC is the settlement system for most - around $96 \%$ - of the central government's domestic securities. SELIC started its operations in 1979, resulting from a joint effort of BCB and market participants represented by the National Association of Financial Market Institutions (Andima). Since then, all the relevant government securities in Brazil were dematerialized and kept in custody in SELIC. 
ve requirement of demand and time deposits, to limit credit expansion. Moreover, there was also an increase in reserve requirements for short selling operations in the foreign exchange market to avoid high volatility and systemic risk. From August, COPOM envisaged substantial deterioration of the international economic scenario, particularly with regards to mature economies. This could have affected the Brazilian economy through several channels, such as: reduction of trade flows, moderate investment flows, more restrictive credit conditions and a worsening perception from a consumer and entrepreneurial points of view. Therefore, COPOM evaluated that the risk of a high inflation rate was reduced and the SELIC rate continued its downturn.

In 2012, COPOM kept its assessment of a troubled and complex international scenario. In order to mitigate the effect of a more restrictive global economic context and reverse GDP fall, it decreased the SELIC rate further, which reached $7.25 \%$ at the end of the year. This was the lowest rate since 1999, when the inflation targeting regime was established in Brazil. But, even though inflation had been within the target band determined by Banco Central, the GDP had a mere 1\% growth, suggesting that the relation between inflation and national gross product is extremely complex and that interest rates and monetary transmission mechanisms are obstructed in the Brazilian economy. Barbosa (2012) claims that the obstruction of monetary transmission mechanisms result from the following characteristics: a) significant participation of the Letras Financeiras do Tesouro [Financial Treasure Bills] (LTF) in the composition of the federal public debt; b) truncated term structures of interest rates; c) significant segmentation of credit markets; d) low levels of free credit penetration in the process of determining income and e) high participation of administered prices in the composition of the official inflation rate index - Indice Nacional de Preços ao Consumidor Amplo [Broad National Consumer Price Index] (IPCA).

After the peak of the subprime mortgage crisis, the strategy of the economic staff of President Dilma Rouseff's government (2001-current) was to promote credit expansion through public banks. From 2010 to 2012 , credit increased by $7.5 \%$ due mainly to the part allocated to directed resources. While the part for free resources was kept at $31 \%$ of GDP, directed resources increased from $16 \%$ to $25 \%$ of GDP (Table 6). 
Table 6 Credit evolution (\% GDP)

\begin{tabular}{lrrrrr}
\hline Resources & $\mathbf{2 0 1 0}$ & $\mathbf{2 0 1 1}$ & $\mathbf{2 0 1 2}$ \\
\hline Free & 30.2 & 31.5 & 31.8 \\
\hline Directed & 16.1 & 17.5 & 24.9 \\
\hline Total & 46.4 & 49.1 & 53.9 \\
\hline
\end{tabular}

Source: Provided by the authors based on BCB/Inflation Report, 2011, 2012, 2013.

It is worth noticing that about $60 \%$ of total directed credit came from BNDES: housing finance represented $22 \%$ and rural credit $15 \%$. The bank distributed its resources as follows: Trade and service sectors received about $60 \%$ of total resources in 2011 and $46 \%$ in 2012, with emphasis on land transportation and electric power sectors; industry received $30.4 \%$ in 2011 and $46.1 \%$ in 2012, with emphasis on the petrol fuel, machinery and equipment sectors. Animal farming received only $6.3 \%$ of the total directed credit in 2012. (Figure 6).

\section{Figure 6 BNDES disbursement (\%)}

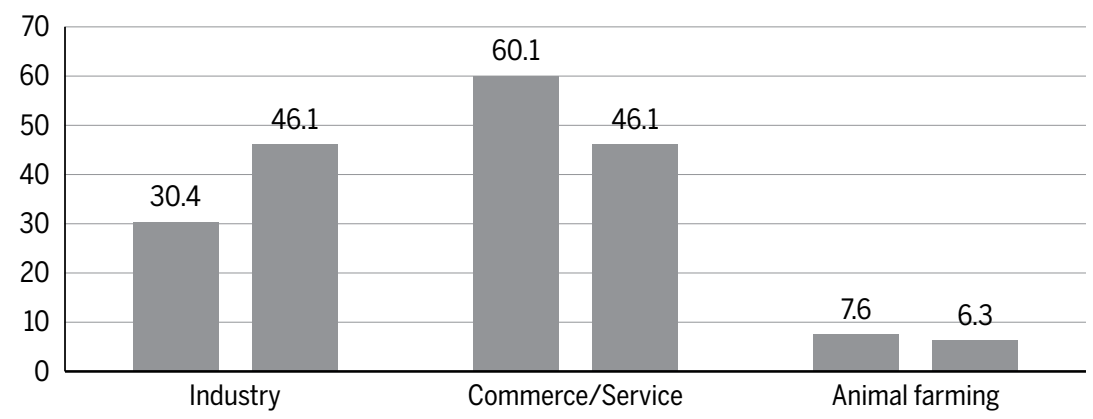

Source: Provided by the authors based on BCB, Inflation Report, 2012.

We claim that public banks succeeded in the application of countercyclical measures at the peak of the subprime mortgage crisis. However, even though directed credit was increasing, with the escalation of the crisis what drove the economy was not investment but rather household consumption. According to Banco Central's 2012 Inflation Report:

Domestic demand continued to be the main economic support with household consumption driven by the moderate credit expansion, of job and income generation. /.../ the level of investment did not set off due to agents' lack of confidence. (Inflation Report. Banco Central do Brasil. December/2012, p.77). 
This statement is in line with Minsky's (1986) 'Hypothesis of Financial Instability' which argues that an adequate governmental stability policy does not hold long in modern economies because its impacts on the agents' expectations encourage instability. This is inherent to the capitalist system. In times of boom, euphoria spreads and increases the level of the agents' debt. In this sense, an adequate policy for economic expansion should be implemented with care so as to avoid a very high level of agents' debt, particularly speculative Ponzi units.

Obstructed monetary transmission mechanisms coupled with a recessive international scenario and decreasing levels of agents' confidence hindered economic recovery in Brazil between 2010 and 2012, contrary to the successful countercyclical policies implemented during the peak of the 2008 crisis.

\section{Concluding remarks}

From the arguments presented in this paper, we can infer that banks play a key part in economic development. Not only are they financial intermediaries, but are also active agents, with both sides of their balance sheet affecting economic financial conditions and the general level of economic agents' expenses, thus influencing real economic variables. The role of public banks in the economy goes beyond being simple commercial banks. Our findings show that they are strongly needed to stabilize financial crises, create a favorable environment for businesses and improve business expectations. Under this viewpoint, profitability should not be the first and foremost concern of public banks. In fact, while public banks act to develop and enforce new market policies, its financial performance plays a secondary role.

As far as Brazil is concerned, public banks played a significant role during the subprime mortgage crisis (2008-2009) and afterwards (2010-212) as well. While in the 1990s the role of public banks was reduced, in the 2000s their relevance was restored, particularly after 2003, as they became active agents of governmental policy and economic development. The post-1990 period presented several important liberal reforms, such as privatization programs and the restructuring of the financial system by means of PROER and PROES. 
At the peak of the subprime mortgage crisis, the Brazilian public banks were assigned to reverse deterioration of expectations and cash pools by increasing their share of credit granting when compared to private banks in 2009. On the other hand, monetary policy was underused, as Banco Central did not make use of all available tools. The monetary authority made an attempt to foster liquidity through reserve requirements and open market operations. However, some other monetary policies adopted were not countercyclical measures, rediscount policy was not employed and the fall in flat interest rates took place very late.

In 2000, the monetary policy changed to insure inflation's convergence to the center of the target band by increasing the SELIC rate. Credit granting through public banks continued to expand, led by household consumption and durable goods. In 2011 and 2012, the government implemented expansionary monetary and credit policy, fearing a global recession scenario. The SELIC rate reached its lowest level and, in particular, BNDES continued to expand credit granting. Nevertheless, GDP did not increase as expected and inflation got out of the central target band. The reason for this outcome is complex, but it might be explained by obstructed monetary transmission mechanisms combined with a global recession scenario, low levels of confidence and excessive household debt hindering Brazil's economic recovery. To conclude, the expected sustainable growth was never achieved and the economy has gone through periods of short cycle expansion followed by slow economic growth so far.

\section{References}

ALMEIDA, Júlio Gomes de. Como o Brasil Superou a Crise. In: PAULA, L. F. R.; FERRARI, F. (Org.). Dossiê da Crise II, v. 2, p.57-62, ago. 2010. Available at: <http://www.ppge.ufrgs.br/ akb/dossie-crise-II.pdf $>$. Accessed on: December 2010.

BANCO CENTRAL DO BRASIL (BCB). Annual Report 2008. Available at: <http://www.bcb. gov.br/pec/boletim/banual2008/rel2008p.pdf>. Accessed on: July 2012.

BANCO CENTRAL DO BRASIL (BCB). Annual Report 2009. Available at: <http://www.bcb. gov.br/pec/boletim/banual2009/rel2009p.pdf>. Accessed on: July 2012.

BANCO CENTRAL DO BRASIL (BCB). Time Series. Available at: <http://www.bcb.gov. br/?SERIETEMP>. Accessed on: December 2012.

BANCO CENTRAL DO BRASIL (BCB). Legislation and Norms. Available at: < http://www. bcb.gov.br/?NORMS>. Accessed on: February 2012. 
BANCO CENTRAL DO BRASIL (BCB). Credit and Banking Report, 2008. Available at: <http:// www.bcb.gov.br/Pec/Depep/Spread/relatorio_economia_bancaria_credito2008.pdf $>$. Accessed on: December 2010.

BANCO CENTRAL DO BRASIL (BCB). Credit and Banking Report, 2009. Available at: $<$ http:// www.bcb.gov.br/pec/depep/spread/REBC2009.pdf>. Accessed on: December 2010.

BANCO CENTRAL DO BRASIL (BCB). Inflation Report, 2011. Available at: http://www.bcb. gov.br/htms/relinf/port/2011/12/ri201112P.pdf>. Accessed on: July 2012.

BANCO CENTRAL DO BRASIL (BCB). Inflation Report, 2012. Available at: < http://www. bcb.gov.br/htms/relinf/port/2012/12/ri201212P.pdf>. Accessed on: July 2012.

BANCO CENTRAL DO BRASIL (BCB). Inflation Report, 2013. Available at: <http://www.bcb. gov.br/htms/relinf/port/2013/12/ri201312P.pdf>. Accessed on: January 2013.

BANCO NACIONAL DE DESENVOLVIMENTO ECONOMICO. National Destatization Program. Available at: <http://www.bndes.gov.br/SiteBNDES/bndes/bndes_pt/Institucional/ BNDES_Transparente/Desestatizacao/index.html>. Accessed on: December, 2012.

BARbOSA, R. M. Mecanismos de Transmissão da Política Monetária e Nivel da Taxa de Juros no Brasil: existe relação? Dissertação Mestrado em Economia. - IE, Universidade Federal do Rio de Janeiro, Sep. 2012. Available at: <http://www.ie.ufrj.br/images/pos-graducao/ ppge/Ricardo_Menezes_Barboza.pdf>. Accessed on: December 2012.

BORÇA JUNIOR, G.; TORRES FILHO, E. T. Analisando a Crise do Subprime. Revista BNDES, p.129-159, Dec. 2008.

CAMARGO, P. O. A Evolução Recente do Setor Bancário no Brasil. São Paulo: Editora UNESP; São Paulo: Cultura Acadêmica, 322 p., 2009.

CAPRIO, G.; FIECHTER, J.; LITAN, R.; PORMELANO, M. The Future of State-owned Financial Institution. Washington: Brookings Institution Press, Sep. 2004.

COELHO, C. A. Três Ensaios sobre Microeconomia Bancária Aplicada. Pontifícia Universidade Católica (PUC-Rio), Tese de Doutorado em Economia. Rio de Janeiro, p.172, 2007.

FRAGA, A. Instituto Liberal, Armínio Fraga's Interview to Rodrigo Constantino. Available at: http://www.institutoliberal.org.br>. Accessed on: July 2013..

FREITAS, M. C. P. Dinâmica Concorrencial e BPs: Questões Conceituais. In: JAYME Jr., Frederico G.; CROCCO, Marco (Org.). BPs e desenvolvimento, Rio de Janeiro, IPEA, p.329-359, 2010.

FREITAS, M. C. P. Os Efeitos da Crise Global no Brasil: Aversão ao Risco e Preferência pela Liquidez no Mercado de Crédito. Estudos Avançados, São Paulo, v.23, n.66, p.125-145, 2009.

INTERNATIONAL MONETARY FUND, International Finance Statistics. Avaiable at: <http:// www.imf.org/external/data.htm>. Accessed on: July 2013.

GERSCHENKRON, Alexander. Economic Backwardness in Historical Perspective, Cambridge, MA: Harvard University Press, 1962.

GUINLE, A. C. B. A Regulação Bancária no Brasil. Dissertação (Mestrado em Economia) - Escola de Pós-graduação da Fundação Getúlio Vargas (EPGE), Rio de Janeiro, 1999.

GURLEY, J.; SHAW, E. Financial Aspects of Economic Development. American Economic Review, v. 14, n. 4, p. 515-538, Sep. 1955.

HERMANN, J. O Modelo de Liberalização Financeira dos Anos 1990: "Restatement" ou Au- 
to-crítica? Revista Nova Economia, Belo Horizonte-13 (2)-137-172-julho-dezembro de 2003.

HERMANN, J. O Papel dos Bancos Públicos, Texto de Discussão nº 15, Cepal-IPEA 2010.

KEYNES, J. M. The General Theory of Employment, Interest, and Money. New York: Classic Books American.2009.

LA PORTA, R.; LOPES-DE-SILANES, F.; SHLEIFER, A. Government ownership of Banks. NBER, WP.7620, March 2000.

MESQUITA, M.; TORÓS, M. Considerações sobre a Atuação do Banco Central na Crise de 2008. Trabalho para Discussão n. 202. Brasília: Banco Central do Brasil, mar. 2010.

MCKINNON, R. Money and Capital in Economic Development. Brookings Institution, 1973.

MINSKY, H. Stabilizing an Unstable Economy. New Haven: Yale University Press, 1986.

MISHKIN, F. S. The Economics of Money Banking and Financial Markets, Pearson Addison Wesley, 2004.

MYRDAL, G., Asian Drama, New York: Pantheon, 1968.

OREIRO, J. L.; PAULA, L. F.; BASILIO, F. A. Desenvolvimento Financeiro e Crescimento Econômico: Teoria e evidência. Sección de Estudios del Desarrollo (230): 3-39, 2010.

PAULA, L. F. R.; OREIRO J. L.; BASILIO F. A. Estrutura do Setor Bancário e o Ciclo Recente de Expansão do Crédito: O Papel dos BPs Federais. Revista Nova Economia 23 (3), 2013.

PUGA F. P. Sistema Financeiro Brasileiro: Reestruturação Recente, Comparações Internacionais e Vulnerabilidade à Crise Cambial. Texto para Discussão 68, BNDES, 1999.

STUDART, Rogério. O Sistema Financeiro e o Financiamento do Crescimento: Uma Alternativa Pós-Keynesiana à Visão Convencional. Revista de Economia Política, vol.13, no 13 (49), p.101-118, jan-mar 1993,

SHAW, E. S. Financial Deepening in Economic Development. New York: Oxford University, 1973.

STIGLITZ, J. E.; WEISS, A. Asymmetric Information in Credit Markets and its Implications for Macroeconomics. Oxford Economic Papers, n.44, 1992, p.162-92.

THORTON, J. A. Framework for Successful Development Bank. Development Bank of Southern Africa, WP 25, 2011.

VELASCO JR., L. A Privatização no Sistema BNDES, Revista do BNDES 33, jun. 2010.

\section{About the authors}

ElenaSoihet-e.soihet@globo.com

Associate Professor, Department of Economics, Rural Federal University of Rio de Janeiro (UFRRJ), Campus Nova Iguaçu, RJ.

Cesar Murilo Nogueira Cabral - cesar.cabral@yahoo.com.br

Graduated in Economics, Rural Federal University of Rio de Janeiro (UFRRJ), Campus Nova Iguaçu, RJ.

\section{About the article}

Submission received on February 25, 2013. Approved for publication on June 15, 2015. 